\title{
Drug Detection Dogs and the Growth of Olfactory Surveillance: Beyond the Rule of Law?
}

\author{
Amber Marks1
}

\begin{abstract}
Since the introduction of the Human Rights Act 1998 in the United Kingdom, a significant expansion in the use of drug detection dogs, the most common tool of olfactory surveillance, has taken place with relatively little debate, without specific legislative authority and in the absence of a code of practice. In contrast, the use of the dogs in New South Wales, Australia and in the United States has been the subject of Supreme Court decisions, and in New South Wales, of parliamentary legislation and an independent review by the New South Wales Ombudsman. This paper will argue that the difficult legal issues raised by olfactory surveillance are similar to those raised by other forms of 'new surveillance' in the criminal justice system and that the failure of the legal system to deal with these issues in the case of olfactory surveillance could amount to a dangerous precedent for the regulation of other surveillance technologies.
\end{abstract}

\section{Introduction}

John and Maguire have defined police surveillance as 'a wide range of methods of monitoring the behaviour, lifestyles or property of suspected or potential offenders- not just visual and optical, but aural, olfactory and electronic' (John and Maguire, 1998: 42). Olfactory surveillance is the monitoring of odour. There are a variety of means for collecting odour (the electronic nose, Fido sensor, insect sensors, dogs etc) and a broad range of information that can be obtained from odours detected (including personal identity, emotional state, physical health). The police use of olfactory surveillance to detect cash, DVDs, mobile telephones, firearms, explosives and drugs has been heavily documented in mainstream media. In this paper I will focus on the police use of dogs to detect the odour of illegal drugs.

Drug detection dogs are used to enable the police to detect odours undetectable by human senses. In this context, a dog is a technology'. 'Technology' is defined in the New Oxford

${ }^{1}$ School of Law, King’s College, London. mailto:amber.marks@gmail.com 
English Dictionary as 'the application of scientific knowledge for practical purposes'. Drug detection dogs are trained in accordance with Pavlovian classical conditioning to recognise the scent of illegal drugs and to indicate their presence to their handlers. Their use is part of the 'new surveillance' described by Gary Marx:

New surveillance is the use of technical means to extract or create personal data. This may be taken from individuals or contexts. In this definition the use of "technical means" to extract and create the information implies the ability to go beyond what is offered to the unaided senses or voluntarily reported.

(Marx, 2002: 12)

It is the technical means by which this information is obtained that makes the surveillance intrusive because it permits information reasonably expected or assumed to be confidential to be obtained:

In extending the senses ...they challenge fundamental assumptions about personal and social borders (these after all have been maintained not only by values and norms and social organization, but by the limits of technology to cross them).

(Marx, 2002: 16)

In the United Kingdom, a significant expansion in the use of police drug detection dogs has taken place over the last decade (Gordon, 2003). Drug detection dogs are now regularly deployed on public transport routes, in schools and on licensed premises. This development has taken place with relatively little debate, without specific legislative authority and in the absence of a code of practice. Their deployment has not been subjected to any scrutiny and its justifiability is yet to be determined. There is yet to have been any challenge to the use of drug detection dogs in any court in England and Wales. As with many new surveillance technologies, the rapid expansion in their deployment and lack of public debate has meant that the challenges posed have received little public attention. I seek to identify the legal implications of the UK police's use of drug detection dogs by first identifying the legal framework within which they operate and then examining the extent to which the use of drug detection dogs has engaged with this framework in the United States and Australia. I will then contextualise the use of police drug detection dogs in the UK within the legal framework before concluding with some observations on the possible implications of the failure to properly regulate their use.

\section{The legal framework}

The aim of the rule of law and the right to privacy is to protect the citizen from arbitrary interference by authorities. Until relatively recently, surveillance by the police and security services in the United Kingdom was entirely unregulated by statute. The principal exception was the Police and Criminal Evidence Act 1984, which requires lawful authority for stops and searches and prescribes police powers of stop and search. 'Search' is not defined in the legislation and is traditionally interpreted as involving physical intrusion that would amount to an 
assault in the event of the statutory conditions required for a search not being satisfied. The general pre-requisite for the exercise of police powers of search is reasonable suspicion. The requirement of reasonable suspicion is the mechanism whereby the state ensures that official action will not be arbitrary (Cohen 1983). Unfocussed trawling for evidence is discouraged by the European Court of Human Rights and such practices are usually referred to as 'fishing expeditions' (Cousens, 2004). The rule of law had until recently, protected the right to privacy only to the extent of holding that police are subject to the same laws as ordinary citizens (the concept of constables as 'citizens in uniform') and that no one is punishable or can be lawfully made to suffer except for a distinct breach of law (Dicey, 1885).

The limited legal protection afforded to the citizen's right of privacy when faced with technical surveillance resulted in legal challenges to police tactics. Domestic courts found that this form of surveillance was not unlawful in English and Welsh law. In a series of decisions in the 1980s and 1990s, the European Court of Human Rights held that the lack of legal regulation of phone tapping and listening devices meant their use breached the privacy of those listened in on ${ }^{2}$ As a result, domestic legislation for the prescription of listening devices was introduced.

The position in the United Kingdom has changed since the introduction of the Human Rights Act 1998. It is now unlawful for a public authority to act in a way incompatible with a convention right. The right to privacy can be defined as the right of the individual to determine for themselves when, how and to what extent they will release personal information about themselves. Article 8 of the European Convention of Human rights provides that any interference with the right to privacy will only be lawful if it is in accordance with the law (the principle of legality), in pursuit of a legitimate aim (which in relation to police surveillance would be the prevention and detection of crime), and a necessary and proportionate response to that aim (the principle of proportionality). In order to satisfy the principle of legality the policing method requires a clear basis in law: either in an Act of Parliament or a common law rule. A Home Office Circular or set of guidelines is incapable of satisfying this requirement. ${ }^{3}$

The relevant law must be sufficiently precise to enable citizens to be aware of the circumstances in which it is applied; the categories of people liable to be the subject of surveillance and the category of offence which would entitle the police to use such techniques must be clearly defined. In order to satisfy the test of proportionality the police must take only such measures as are strictly necessary to achieve the required objective and the degree of intrusion into privacy must not outstrip the importance of the aim pursued (Colvin and Noorlander, 1998).

The incorporation of the European Convention on Human Rights into English law has led the Government to introduce the Data Protection Act 1998 and the Regulation of Investigatory Powers Act 2000. The aim of this legislation was to provide an all-encompassing legal structure for the prescription of surveillance (Taylor, 2002). How all encompassing the legislation actually is, is debatable. It might be that olfactory surveillance could be embraced by the legislation. No mention of it is made in any of guidance issued pursuant to it. Closed Circuit Television was

\footnotetext{
2 Malone v Uk (1984) \& EHRR 14; Halford v UK (1997) 24 EHRR 523; Khan v UK (2001) 31 EHRR 45

3 Klass v Germany (1978) 2 EHRR 214; Malone v United Kingdom (1985) 7 EHRR 14
} 
included in the remit of the Data Protection Act 1998 only after the House of Lords Select committee on Science and Technology highlighted a concern about a lack of regulation and central guidance in this area (House of Lords Select committee on Science and Technology, 1998). CCTV has been the subject of a large amount of research in recent years and this has contributed to the perceived need for its regulation.

\section{The regulation of drug detection dogs in the United States}

The US Supreme Court has recently recognized the threat to privacy posed by new surveillance techniques in Kyllo v. United States. In that case the police had aimed a thermal-imaging device at the appellant's residence to detect heat emanations associated with high-powered marijuanagrowing lamps. Based on the thermal-imaging information, police obtained a search warrant for the residence. The Court held that when the police obtain by sense-enhancing technology any information regarding the interior of the home that could not otherwise have been obtained without physical intrusion into a constitutionally protected area, that constitutes a search, at least where the technology in question is not in general public use $\mathrm{e}^{4}$. The Court observed that this would assure preservation of that degree of privacy against government that existed when the Fourth Amendment (the U.S. equivalent to Article 8) was adopted.

Kyllo illustrates that the concept of physical intrusion needn't be an impediment to expansion to the definition of a search but can, on the contrary, facilitate it. The recent US Supreme Court case of Illinois $\mathrm{v}$ Caballes illustrates that the principal impediment to proper consideration of police powers is a judicial reluctance to protect the right to privacy from advancing police technology and that the concept of 'citizens in uniform' is only one of any number of means of expressing this reluctance. In Illinois v Caballes the Court relied on an assumption that the detection dog is an infallible detection tool to avoid dealing with the constitutional principle at stake.

In holding that the sniff of a well trained dog in the detection of contraband did not amount to a search the majority distinguished the case from Kyllo on the basis that:

Critical to that decision was the fact that the device was capable of detecting lawful activity--in that case, intimate details in a home, such as "at what hour each night the lady of the house takes her daily sauna and bath." [...] The legitimate expectation that information about perfectly lawful activity will remain private is categorically distinguishable from respondent's hopes or expectations concerning the non-detection of contraband in the trunk of his car. A dog sniff conducted during a concededly lawful traffic stop that reveals no information other than the location of a substance that no individual has any right to possess does not violate the Fourth Amendment.

\footnotetext{
${ }^{4}$ Danny Lee Kyllo v. United States 533 U.S. 27,121 S. CT. 2038, 150 L. ED. 2D 94; 2001 U.S. LEXIS 4487. The case can be contrasted with the finding by the Canadian Supreme Court that the use of infa-red imaging equipment to detect the growing of cannabis did not violate the right to privacy on the particular facts of the case: Tessling [2004] S.C.C.7 reported in C.L.R. 2005 167-168
} 
Ginsburg J, dissenting, observed the dangerous precedent established in the majority judgment: 'The Court has never removed police action from Fourth Amendment control on the ground that the action is well calculated to apprehend the guilty.' The European Commission of Human Rights has observed on this point that if the field protected by the right to privacy were limited to those aspects of private life in which the public authorities have no interest, article 8 would be largely divested of its substance and that the criminality of the information: 'is a consideration relevant to the question whether the interference is justified, but does not disprove the very existence of that interference. ${ }^{5}$

Souter $\mathrm{J}$, also dissenting, pointed out that the assumption that the detection dog is infallible is in any event a false factual premise: 'The infallible dog...is a creature of legal fiction.' Souter J quoted from a body of expert evidence relied on in this case which showed that dogs gave false positives between $12-60 \%$ of the time and that $80 \%$ of US bank notes was contaminated with sufficient traces of controlled substances to cause a trained dog to alert to their presence. Souter J held that:

in practice the government's use of a trained narcotics dog functions as a limited search to reveal undisclosed facts about private enclosures, to be used to justify a further and complete search of the enclosed area. And given the fallibility of the dog, the sniff is the first step in a process that may disclose "intimate details" without revealing contraband, just as a thermal-imaging device might do.

Importantly, Souter J, recognized that Kyllo and Illinois v Caballes raised the same issue; the engagement of privacy in the use of new surveillance technologies;

in practical terms the same values protected by the Fourth Amendment are at stake in each case. The justifications required by the Fourth Amendment may or may not differ as between the two practices, but if constitutional scrutiny is in order for the imager, it is in order for the dog.

Souter $\mathbf{J}$ opined that the use of a drug detection dog is an intrusive procedure in itself and relied on the reason given by Ginsburg $\mathbf{J}$ that a drug-detection dog was 'an intimidating animal' and its use 'exposed [the suspect] to the embarrassment and intimidation of being investigated, on a public thoroughfare, for drugs.'

Only by acknowledging the constitutional point at stake were members of court able to grapple with the challenges posed by this form of surveillance. Ginsburg J, for example pointed out that the minority judgment on the illegality of the dog sniff might be different if the dog was an explosive detection dog because the need for reasonable suspicion might not apply if there was an immediate danger of a terrorist attack and all persons were being subjected to dog sniffs for that reason. Souter J points out the dangers of the majority decision by stating that adherence to it:

\footnotetext{
5 A v France (1993) 17 EHRR 462 at page 472
} 
would render the Fourth Amendment indifferent to suspicionless and indiscriminate sweeps of cars in parking garages and pedestrians on sidewalks; ... [the use of drug detection dogs] escapes Fourth Amendment review entirely unless it is treated as a search.

As illustrated by the Souter J's dissenting judgment in Illinois v Caballes, the Courts in the United States are beginning to question the assumption that the dog is a reliable detection tool. This has implications for determining whether an indication from a dog can amount to reasonable grounds for conducting a traditional search. In the District Court of Appeal of Florida in the case of Mathieson it was held that the prosecution bore the burden of proving the existence of reasonable grounds and the fact that dog had been trained and certified by the relevant body was not in itself sufficient to overcome that burden. The prosecution would have to prove that the officer reasonably believed that the dog would only exhibit the alert behaviour if contraband was present; that the dog was trained to refrain from alerting to residual odours and provide a record of the dog's false alert rate.

\section{The Regulation of Drug Detection Dogs in New South Wales, Australia}

The lack of regulation of drug detection dogs in the United Kingdom can also be contrasted with the position in New South Wales where the Police Powers (Drug Detection Dogs) Act 2001 commenced in February 2002. ${ }^{6}$ It was introduced following a local court decision in Police v Darby in which the magistrate held that the behaviour of the sniffer dog amounted to an illegal search and excluded the evidence of the drugs found as a result on the grounds that offence of cannabis possession was not 'so criminally serious' and that the implications for civil liberties of the police practice were 'so great'. A range of views were expressed in NSW Parliament about the degree of embarrassment that might be associated with an approach by a drug detection dog and whether such embarrassment was an acceptable consequence of enforcing the state's drug laws. Several community-based organisations (including Redfern Legal Centre and the NSW Council for Civil Liberties) have opposed the use of the drug detection dogs on the basis that the use of the dogs infringes civil liberties and the privacy of persons sniffed and searched.

The Police Powers (Drug Detection Dogs) Act was introduced with a primary goal of targeting drug supply related offences. The Act authorizes a police officer to use a drug detection dog to sniff a person the police officer is already authorized to search for the purpose of a drug offence. The Act further enables police to carry out 'general drug detection' without a warrant in authorized public places such as licensed premises, sporting and entertainment venues, and prescribed public transport routes. Police may also carry out 'general drug detection' in other public places such as streets and shopping centres upon obtaining a warrant pursuant to the act.

The Act does not refer to the use of drug detection dogs as a 'search' but the legislation amounts to recognition that their use as an investigative tool requires regulation and parliamentary scrutiny.

\footnotetext{
6 The substantive provisions of the Act have been moved to Part 11 of the Law Enforcement (Powers and Responsibilities) Act 2002
} 
Included in the $\mathrm{Act}^{7}$ was a requirement that the NSW Ombudsman scrutinize and report on the initial police use of powers conferred by the legislation. The Ombudsman's report is due to be published in November 2006. An interim discussion paper was published in 2004 and outlined some of the issues that had been raised by their research. The review employed a range of research methodologies including consulting with stakeholders such as police and community groups; direct observation of police using drug detection dogs; inspecting records of police use of the powers; examining court decisions; and analyzing complaints.

From 22 February 2002 to 21 February 2003 the drug detection dogs made an indication of the presence of an illegal substance on 4078 occasions. Police located drugs in 1110 (27\%) of the 4078 searches conducted after drug dog indications. No drugs were found in the remaining 2968 searches $(73 \%$ ). Cannabis was the most commonly located drug. On approximately $61 \%$ of occasions on which police found no drugs, the person searched made some kind of admission that they had personally smoked cannabis or had been around people smoking cannabis. The data they have examined to date indicate that when drugs are found following drug detection dog indications, the quantity is usually below the amount necessary for a charge of 'deemed supply.'

Many police observed or spoken with during the course of the Ombudsman's review consider that a person's reaction to a drug detection dog might provide them with the reasonable suspicion necessary to search a person according to the Drug Misuse and Trafficking Act 1985 (NSW). The review observes that the notion that a person's avoidance of a drug detection dog could provide police with the suspicion necessary to search a person is complicated by the fact that some people appear to be genuinely afraid of the dog. Their avoidance may be because of this fear.

Amongst the questions put forward for consideration in the discussion paper are the following: (a) Police have located drugs in approximately $27 \%$ of searches conducted as a result of drug dog indications. In the context of this rate of finding drugs, is it reasonable to suspect that a person is carrying illegal drugs solely on the basis of an indication by a drug detection dog? (b) Does the practice of searching persons who have had some prior contact with cannabis, either through their own use or from being in the vicinity of others' use, reflect fair and effective drug law enforcement? (c) In what circumstances might it be reasonable to base a decision to search a person on that person's reaction to a drug detection dog?

The NSW Council for Civil Liberties (CCL) submission to the NSW Ombudsman's discussion paper (Cripps et al., 2004) stated that drug detection dogs are being used by police:

\footnotetext{
7 Section 13

8 'Deemed supply' means that although police may have no other evidence that the person found in possession of drugs was dealing or supplying drugs, the amount of drugs in the person's possession indicates that the drugs were not for personal use. The weight or quantity of drugs required for a deemed supply charge are prescribed in legislation and vary according to the drug type.
} 
as an excuse to trawl the community. The dogs are being used not so much for drug detection but rather to arbitrarily stop, search and detain citizens police would not otherwise be able to.

In some local area commands, the Ombudsman noted that records with a person's identification details appeared to be made on the police database as a matter of course, whether or not any drugs were found on the person and regardless of whether an admission of drug use was made. The Ombudsman expressed concern that members of the public, who had committed no offence and made no admissions, and about whom police had no prior intelligence information, were having their details recorded on the database solely because of an indication by a drug detection dog. The Ombudsman expressed concern that this record had the potential to prejudice future police dealings with this person. According to the CCL the police routinely check to see if there are any outstanding warrants in relation to the persons indicated, even when a search has revealed that police officers' suspicion that they were carrying drugs was mistaken. According to research conducted by the CCL, persons searched are given the misleading impression that they have to supply their personal details as a result of being indicated by the dog.

The CCL argues that the inaccuracy of the dogs is compounded by the unwillingness of their handlers to admit to it because the police "will carry a search quite far to discover those (nonexistent) drugs'. The police's blind faith in the accuracy of their dogs has been shown to prevent the police from being polite or apologetic following a negative search and to instead persist in suspecting the person of involvement with illegal drugs. The Ombudsman and the CCL response both document the existing practice of asking persons searched and no drugs found on them, to explain why the dog had indicated them to the handler. The person who has been searched should not have to divulge personal information when a search has revealed that they are not in possession of any prohibited substances. The CCL observes that the fact that persons indicated had recently used drugs or been in the presence of those who had did not alter the fact that the dogs cannot accurately detect people in actual possession of prohibited drugs, let alone those in possession of large quantities, which was the primary purpose of the Drugs Dog Act. ${ }^{9}$ Any admission to recent drug contact should not therefore be relied on by the police in testaments to their effectiveness. Requests for such information are an unjustifiable invasion of privacy and the fact that they are made supports the concern that new surveillance techniques are often used to monitor unconventional (not criminal) behaviour and to control members of marginalized groups (La Forest, 2002).

It is clear from the judicial approach to drug detection dogs in New South Wales that without the legislation, their use is unlikely to have been subjected to any meaningful scrutiny. In Darby v DPP, the NSW Supreme Court overruled the magistrate's finding that the dog's behaviour had amounted to an illegal search. The facts of the case were, briefly: a plain clothed police officer trained in dog handling, and other police officers took up positions near to a nightclub in order to detect illegal drugs. As the defendant walked past, the dog flared its nostrils, sniffed the air and

9 During debate on the Police Powers (Drug Detection Dogs) Act, the NSW Police Minister said in Parliament that: 'The Bill is aimed primarily at detecting and prosecuting persons committing offences relating to the supply of prohibited drugs or plants.' Michael Costa, Minister for Po lice), New South Wales, Parliamentary Debates, Legislative Council, 6 December 2001, 19745 second reading speech. 
then sniffed about until he headed straight towards the defendant, at which point the dog then sniffed around the defendant's genital area, his trousers and his pockets and put his nose directly onto the outside of the defendant's pocket and sat down. Police officers then searched the defendant, finding cannabis.

The Supreme Court found that the dog's behaviour did not amount to an unlawful search on the basis that:

A police officer would have been entitled to walk in the vicinity of the appellant and, if he were able to smell cannabis leaf in the appellant's possession, form a reasonable suspicion sufficient to entitle him to search the appellant. He would not thereby commit trespass to the person. Treating a drug detection dog as an extension of the police officer, an aid to his olfactory senses, the position is unchanged. It matters not that the dog acts differently from the police officer in the way he detects and indicates, short of bunting and ferreting and putting his nose on a pocket, the presence of a substance, or that the dog acts under the encouragement of the police officer. There is still not a trespass to the person, and there is not a search ${ }^{10}$....the generally accepted connotation of search is that it involves looking carefully in order to find something that is hidden. When it relates to a person, it carries the implication of some physical intrusion onto the person (for example by patting down the clothing of such person) or into the clothing or body of the person the subject of the search. ${ }^{11}$

The only reference in the NSW Supreme Court judgment to the US Supreme Court case of Kyllo was to observe: 'That is distant from the present case.' 12

The Supreme Court's judgment in Darby might be used by some as an illustration of how the 'The ideology of constables as 'citizens in uniform' operates as an impediment to proper consideration of the nature of police powers' in failing to recognize that police powers are such that they do not need to commit an offence (e.g. trespass or assault) to ascertain information about the citizen (Dixon, 1997). However the US Supreme Court in Kyllo used the traditional concept of trespass and assault and their association with physical intrusion to justify expanding the concept of 'search' to include new surveillance techniques. In concluding that use of the thermal-imaging device was a search, the Court in Kyllo stressed that the "Government [may not use] a device . . . to explore details of the home that would previously have been unknowable without physical intrusion."

\footnotetext{
10 at para 62

11 at para 120

12 ibid at para 68 


\section{A Legal Basis forthe use of Drug Detection Dogs in the UK?}

The only power the police have to search persons in relation to controlled drugs is contained in section 23 of the Misuse of Drugs Act 1971. This provides that a constable may search a person, and detain them for the purpose of searching them if a constable has reasonable grounds to suspect that any person is 'in possession of a controlled drug'. A constable carrying out a search under this section is required to comply with Code A of PACE. The primary justification for stop and search powers is to enable officers to allay or confirm reasonable suspicions about individuals without exercising their power of arrest. ${ }^{13}$

Do the police have the power to insist the dog sniffs someone the police do not have the right to search? The Police and Criminal Evidence Act 1984 Code A 2.11 states:

There is no power to stop or detain a person in order to find grounds for a search. Police officers may have many encounters with members of the public which do not involve detaining people against their will. If reasonable grounds for suspicion emerge during such an encounter, the officer may search the person, even though no grounds existed when the encounter began. If an officer is detaining someone for the purpose of a search, he or she should inform the person as soon as detention begins. [emphasis added].

The police evidently do not have a power to stop or detain a person in order for their odour to be monitored by a drug detection dog. The way in which the dogs are deployed should not therefore restrict or delay the person's movement. Accordingly the Association of Chief Police Officers (ACPO) Dog Training Manual states: 'People may not be funnelled or individuals requested to change their direction in order to facilitate the dog's deployment as this may constitute a search.' However, my preliminary research suggests that people are sometimes required to change their direction in order to facilitate the deployment of the dogs. My research also reveals a practice by the police of treating evasive action by persons in relation to drug detection dogs as grounds for a search. There is clearly no legal duty to allow oneself to be sniffed by a police dog unless detained for purpose of a search. There is authority to suggest that behaving in a manner which is uncooperative with the police, but not inconsistent with legal rights, cannot, in itself provide the police with reasonable grounds to search or arrest the person (Samuels and the Commissioner of Police for the Metropolis). I suggest that a search on the ground of evasive action is unlawful.

As well as being unlawful, searches on the ground of evasive action may amount to a dangerous breach of principle. The Code of Practice on CCTV recommends that signs be placed so that the public are aware that they are entering a zone which is covered by surveillance equipment (Information Commissioner). The concept of informed consent to surveillance echoes he principle enunciated in Rice $\mathrm{v}$ Connolly that the citizen is under no legal obligation to assist the police with their inquiries. The House of Lords Select Committee on Science and Technology attaches importance to the principle that all widespread uses of surveillance should have

\footnotetext{
13 PACE Code of Practice paragraph A:2
} 
prominently displayed notices to make members of the public aware of them. At present, when police take drug detection dogs to railway stations, no signs or announcements are made about their presence. It is current police practice to treat the attempted evasions of a drug detection dog as reasonable grounds justifying a stop and search under the Police and Criminal Evidence Act 1984 (Streatham Guardian, 2003). Aside from the fact that a person may have any number of reasons for not wanting to be sniffed by a $\operatorname{dog}{ }^{14}$ the practice goes against the principle of informed consent to surveillance. The reliance by the police on a person's attempted evasion of non-compulsory surveillance as a reasonable ground for searching them under PACE is not the product of parliamentary debate or legislation. The practice has been recently extended to the 'voluntary' compliance with the police use of metal detectors and other forms of electronic screening on London Transport.

As we have seen in the discussion of the case law in the United States and Australia, it is possible to define a dog 'sniff' as a 'search' in which case reasonable grounds of suspicion would need to exist before a dog could sniff a person. The ACPO training manual states that except for where a person is 'funnelled' in order the facilitate the deployment of the dogs '...the use of Passive Alert dogs does not constitute a search.' Their explanation for this assertion is that 'The dog is deployed to scent the air surrounding an individual person and indicate the presence of the smell of category A and B narcotics in the close vicinity of an individual...' ACPO is asserting that because the dog does not physically touch the subject, the action does not constitute a search. There is an internal inconsistency in ACPO's reasoning: it seeks to distance the subject from the source of the odour in order to deny that the surveillance amounts to a search of the subject, and simultaneously, to link the subject to the information obtained from that odour in order to provide a legal basis for any subsequent physical search.

Neither the Home Office nor ACPO appear to have considered the possibility that lawful authority might be needed for the use of drug detection dogs. This failure appears to be based on the outdated assumption that an intrusion that does not involve a physical intrusion does not require a legal basis. The only guidance in relation to the use of drug detection dogs is in the ACPO Police Dog Training and Care Manual (ACPO, 2002). Where the use of drug detection dogs amounts to a breach of privacy, it will be unlawful because it lacks a clear basis in law.

When can an indication from a sniffer dog provide an officer with reasonable grounds to carry out a traditional stop and search? According to the ACPO training manual, it always will: '[T]he indication of an individual person given by a Passive Alert dog provides grounds for a physical search.' The accuracy of a dog's odour detection and discrimination appears to have been taken for granted as a matter of common sense. This practice can also be found in the UK case law on the admissibility of evidence of tracker dogs. ${ }^{15}$ It fails to take account of the large body of scientific research, as well as recent legal decisions in the United States that cast doubt on the accuracy of drug detection dogs. ${ }^{16}$

\footnotetext{
14 eg allergies, fear of dogs, cultural or religious beliefs .

15 R v Oldfield [2000] CA, No 199904125, unreported and R v Whiteman [2005] EWCA Crim 1145

16 Space does not permit an a summary of the literature here but a brief summary is contained in Illinois $\mathrm{v}$ Caballes 
Although the possession and supply of drugs is illegal, it is not clear whether the large-scale deployment of drug detection dogs could be described as a necessary, proportionate and parsimonious response to the prevention and detection of drug offences. In 1971 the Misuse of Drugs Act was not considered to constitute a substantial interference with the liberty of the individual because the number of people using drugs at the time was very small (Advisory Committee on Drug Dependence, 1968). Little was known about the substances being proscribed (Fortson, 1996): the government acted out of caution (Iremonger, 1970). Possession offences were created but the principal strategy was one of supply reduction; the only explanation for the use of drugs among the general population was the existence of a large supply of drugs on the market. It was hoped that if this supply could be eradicated, drug use would desist (Oakes, 1970). The restrictions imposed on individual liberty by the Misuse of Drugs Act can no longer be easily dismissed on the ground that the proscribed substances do not constitute a normal accompaniment of social intercourse According to the 2004/2005 British Crime Survey, an estimated $46 \%$ of 16-24 year olds had tried an illicit substance at some point in their lives, $26.3 \%$ had used an illicit substance in the last year and $16.3 \%$ had use an illicit substance in the last month (British Crime Survey 2004/2005). Recreational drug users are not confined to any particular social class (Parker et al., 1999). ${ }^{17}$ It has been argued that the Misuse of Drugs Act 1971 constitutes a substantial interference with individual liberty in today's society because drug use is regarded as a normal part of leisure by today's younger generation (Parker et al.:1999). Far from reviewing its strategy on drugs in light of the increasing numbers of recreational drug users, the deployment of drug detection dogs amounts to a dramatic increase in its enforcement. In relation to cannabis, it is difficult to see how this accords with the ACPO guidelines on the policing of cannabis. ${ }^{18}$

If the dogs are, in actual fact, mainly deployed to detect drug users, it should be noted that drug use is not in fact a crime. The difference between the possession of a drug and the use of a drug might seem insignificant, but it is the point at which the legal line has been drawn. In Pragliola [1977] Crim. L.R. 612, P was charged with possession of the traces of cannabis found in his pipe. The court held that the charge was oppressive and could not be justified in the circumstances. Police dogs are unable to distinguish between residual scents of illegal drugs and the substances themselves (Marks, 2006). As a result of failing to recognise engagement of the right to privacy by the use of drug detection dogs, neither the categories of people liable to monitoring nor the category of offence which may give rise to such monitoring is anywhere defined. Consequently 'surveillance creep' has gone undetected and members of the public are now being monitored for behaviour that does not amount to a crime. Marx has made the point that such 'fishing expeditions' or generalised 'searches' shift the burden of proof from the state to the target of surveillance (Marx, 2005: 777)

\footnotetext{
17 See Shiner and Newburn (1997) for a critique of the 'normalisation thesis'.

18 ACPO (2003), Cannabis Enforcement Guidance. London: ACPO. For further discussion on the re classification of cannabis see Warburton, H., May, T. and Hough, M. (2005) 'Looking the other way: the impact of reclassifying cannabis on police warnings arrests and informal action in England and Wales', British Journal of Criminology, Vol.45 (2):113-128
} 


\section{Conclusion}

The rejection of the submission that a dog 'sniff' is an intrusion of privacy, on the basis that odours emitted from a person are exposed to the plain perception of the public at large ignores the fact that dogs are used precisely because of their ability to detect and identify odours which are not exposed to the plain perception of the public at large. This paper has sought to illustrate that the use of drug detection dogs engages the right to privacy to the same extent as other new surveillance technologies in revealing personal information that would previously have only been obtainable by physical intrusion.

The refusal to treat a 'sniff' as search renders the constitutional and legislative protection of privacy obsolete in the face of new surveillance technologies. Treating the dog as an 'extension of the police officer' and excluding it from regulation on this ground, as the New South Wales Supreme Court did in Darby v DPP, sets a dangerous precedent because the rationale could be applied to the whole range of surveillance technologies including listening devices. In failing to regulate the use of drug detection dogs, there is a danger that the police deployment of new surveillance tools will develop a logic beyond the reach of the rule of law. This danger is illustrated by police reliance on the mistaken premise that if a person has 'nothing to hide', they will have 'nothing to fear' from their detection dogs and that attempts to evade them should therefore be treated as grounds for suspicion. This is inconsistent with the law and, as illustrated by the empirical research into the accuracy of drug detection dogs conducted in New South Wales, police detection tools are not necessarily as reliable as the police believe. We are therefore right to fear new detection tools, even when we have nothing to hide, because they are reaching beyond the rule of law.

\section{References}

ACPO Police Dog Working Group (2002) Police Dog Training and Care Manual. http://www.acpo.police.uk/asp/policies/policieslist.asp [accessed on 28/03/2006]

ACPO (2003) Cannabis Enforcement Guidance. London: ACPO

Advisory Committee on Drug Dependence (Chaired by Sir Edward Wayne), (1968) Cannabis: Report by the Advisory Committee on Drug Dependence, London: HMSO.

Cohen, S. (1983) Invasion of Privacy: Police and Electronic Surveillance in Canada, Toronto: Carswell.

Colvin, M. and Noorlander, P. (1998) Under Surveillance: Covert Policing and Human Rights Standards, a Justice Report. London: Justice.

The Honorable Michael Costa (Minister for Police), (2001) New South Wales, Parliamentary Debates, Legislative Council, 6 December.

Clayton, R. and Tomlinson, H. (2004) Civil Actions Against the Police, $3^{\text {rd }}$ ed. London: Sweet and Maxwell,

Cousens, M. (2004) Surveillance Law, LexisNexis UK. 
Cripps, A., Murphy, C., Walton, M. (eds.) (2004) Submission of the New South Wales Council for Civil Liberties to the NSW Omb udsman's Discussion Paper 'Review of the Police Powers (Drug Detection Dogs) Act'.

DeCew, J. (1997) In Pursuit of Privacy: law, ethics and the rise of technology. Ithaca NY: Cornwell University Press.

Dicey, A.V. (1885) Introduction to the Study of the Law of the Constitution, 10th ed., Basingstoke UK: Macmillan

Dixon, D. (1997) Law in Policing: Legal Regulation and Police Practices, Oxford: Clarendon Press.

Field, S. and Pelser, C. (eds.) (1998) Invading the Private: State Accountability and New Investigative Methods in Europe, Aldershot UK: Ashgate.

Fortson, F. (1996) Misuse of Drug Trafficking Offences, third edition, London: Sweet and Maxwell

Gordon, K. (2003) A History of the First British Police Dog Section, London: British Transport Police History Society.

http://www.btp.police.uk/History\%20Society/Publications/History\%20Society/The\%20history/The\%20Polic e\%20Dog\%20Pioneers.htm [accessed on 30/3/6]

House of Lords Select Committee on Science and Technology (1998), Digital Images as Evidence, 5th Report, 21 February, HL 64 para 4.22,

http://www.parliament.the-stationery-office.co.uk/pa/ld199798/ldselect/ldsctech/064v/st0502.htm accessed on $30 / 3 / 6$

Information Commissioner, (2000) CCTV Code of Practice, Standards para 7,

http://www.informationcommissioner.gov.uk/cms/DocumentUploads/cctvcop1.pdf [accessed 5/11/04]

Iremonger, T.L. (MP for Ilford, North) (1970) HC Parliamentary Debates 25 March at 1534

John, T. and Maguire, M. (1998) 'Police Surveillance and its regulation in England and Wales' in S. Field and C. Pelser (eds.) Invading the Private: State Accountability and New Investigative Methods in Europe, Aldershot UK: Ashgate.

La Forest, J.(2002) Official website of the Privacy Commissioner of Canada, http://www.privcom.gc.ca/media/nr-c/opinion 020410 e.asp [accessed on 12/11/04]

Marx, G.T. (2002) 'What's new about the 'new surveillance'? Classifying for change and continuity', Surveillance \& Society 1(1): 9-29. http://www.surveillance-and-society.org/articles1.whatsnew.pdf

Marx, G. 'The New Surveillance', extract from Marx (1988) 'The New Surveillance' in Undercover: Police surveillance in America, Berkeley: University of California Press, in T. Newburn (ed.) (2005), Policing: Key Readings, Cullhompton UK: Willan.

Marks, A (2006) 'Science you can Sniff at', The Register, 5 May. http://www.theregister.co.uk/2006/05/12/animal detection/

Oakes, G. (MP for Bolton, West) (1970) HC Parliamentary Debates 25 March at 1505

Parker, H. Aldridge, J. Measham, F. (1999) Illegal Leisure: The Normalisation of Adolescent Recreational Drug Use, London: Routledge.

Roe, S. (2005) Drug Misuse Declared: Findings from the 2004/05 British Crime Survey, Home Office Statistical Bulletin, October 2005. 
Saunders, J. (2004) 'Dogs Track down school pupils’, NLJ, 154 (7131), 844-845.

Shiner, M. and Newburn, T. (1997) 'Definitely, maybe not: the normalisation of drug-taking amongst young people', Sociology 31(3): 511-529.

Streatham Guardian 6/11/03, http://www.streathamguardian.co.uk/display.var.430253.0.0.php [accessed on 31/03/2006]

Taylor ,N. (2002) State Surveillance and the Right to Privacy, Surveillance \& Society 1(1): 66-85. http://www.surveillance-and-society.org/articles1.statesurv.pdf

Warburton, H., May, T. and Hough, M. (2005) 'Looking the other way: the impactof reclassifying cannabis on police warnings, arrests and informal action in England and Wales', British Journal of Criminology, 45 (2):113-128

\section{Cases}

England and Wales

R v Oldfield [2000] CA, No 199904125, unreported

R v Whiteman [2005] EWCA Crim 1145

Rice v Connolly [1966] 2 QB 414

R.(Bonner) v. DPP [2005] A.C.D.56. QBD

Samuels and the Commissioner of Police for the Metropolis decided by the Court of Appeal (Civil Decis ion on 3/3/99) unreported

Supreme Court of South Australia

Questions of Law Reserved (NO 3 of 1998) (1998) SASC 6696

\section{New South Wales}

DPP v Darby [2002] NSWSC 1157

Police v Darby (unreported), Downing Centre Local Court, 21 November 2001

Canada

Tessling [2004] S.C.C.7 reported in C.L.R. 2005 167-168

European Court of Human Rights

A v France (1993) 17 EHRR 462 at page 472

Halford v UK (1997) 24 EHRR 523;

Handyside v UK (1976) 1EHRR 732

Khan v UK (2001) 31 EHRR 45

Klass v Germany (1978) 2 EHRR 214

Malone v UK (1984) \& EHRR 14

PG and JH v UK, Judgment of September 25, 2001 para 56

\section{United States of America}

Danny Lee Kyllo v. United States 533 U.S. 27,121 S. Ct. 2038, 150 L. Ed. 2d 94; 2001 U.S. LEXIS 4487

Illinois v Caballes 125 S.Ct.834, 2005 US Lexis 769

Mathieson v State of Florida, Second Circuit, August 1st 2003, Case No 2D00-1611 